\title{
Az újjáalakult Világgazdasági Tudományos Tanács első évének legfontosabb eredményei
}

(Szanyi Miklós - Török Ádám /szerk./: Trendek és töréspontok. Akadémiai Kiadó. Budapest, 2019, 277 oldal.)

\section{TŐKÉS TIBOR}

a Debreceni Egyetem Gazdaságtudományi Karán a Világgazdasági és Nemzetközi Kapcsolatok Intézet, Európai Integrációs Tanszék adjunktusa.E-mail: tokes.tibor@econ.unideb.hu.

\section{ERDEY LÁSZLÓ}

a Debreceni Egyetem Gazdaságtudományi Karán a Világgazdasági és Nemzetközi Kapcsolatok Intézetének Világgazdasági és Nemzetközi Üzleti Tanszékének docense, intézetigazgató.

E-mail:erdey.laszlo@econ.unideb.hu

A Szanyi Miklós és Török Ádám által szerkesztett tanulmánygyüjtemény a 2017ben újjáalakult Világgazdasági Tudományos Tanács működésének bő első évében megvitatott világgazdasági elemzéseket közli, a hozzájuk kapcsolódó hozzászólások bemutatásával együtt. Török Ádám és Szanyi Miklós bevezetőjét követően a kötet négy témát dolgoz föl. Az első fejezetben Szanyi Miklós a műszaki fejlődés és a hosszútávú gazdasági ciklusok kapcsolatát vizsgálja. A második, Gazdasági csodák/gazdasági csapdák címü fejezetben, Szunomár Ágnes a kínai növekedés lehetőségeit vizsgálja Japán és Dél-Korea példájának figyelembe vételével. A harmadik fejezet témája Oroszország gazdasági növekedése és útkeresése, melyben Deák András azt a kérdést teszi föl, van-e orosz modell? A kötet zárófejezetében Kiss Judit a világkereskedelem átalakulásának lehetőségeit elemzi. Mind a négy témával kapcsolatban két-két a tanács által felkért hozzászóló észrevételeit is megismerheti az olvasó, ezek közvetlenül követik a témát elemző tanulmányokat, kapcsolódva és kiegészítve azokat. Mind a négy téma aktuális és széles érdeklődés övezte területet fed le, melyeket a szerzők objektív szakmai szempontok alapján elemeztek és mutatnak be.

Az első téma a műszaki fejlődés és hosszú távú gazdasági ciklusok. Szanyi Miklós a kötet első fejezetében a műszaki fejlődés és a gazdasági növekedés kapcsolatrendszerét vizsgálja meg úgy, hogy azok hosszú távú ciklusait veti össze egymással. 
A müszaki fejlődés hosszú távú ciklusait a Christopher Freeman és társai által kidolgozott, a Sussexi Egyetem Tudománypolitikai Kutatóegységében megalkotott evolúciós innováció elmélet segítségével kialakított müszaki-gazdasági paradigma koncepció segítségével ismerteti. A gazdasági fejlődés hosszú távú ciklusait pedig a Nyikolaj Kondratyev a gazdaság fejlődésének hosszú hullámait leíró elmélete segítségével mutatja be. A szerző, elemzése során, egymás emellé állította a két elmélet által bemutatott fejlődési pályákat, összehasonlította és párhuzamosította az elméletek alapján kapott eredményeket összefüggéseket. Az evolúciós innovációelmélet szerint a müszaki fejlődési tér, melyet a müszaki tudományos haladás és az elérhető tudás a gazdaság, a piacok és a társadalmi intézmények is befolyásolnak, időben változó, dinamikus folyamat, melynek számos eleme útfüggő, meghatározza a használatba vett müszaki megoldások és technológiák fejlődésének irányát és sebességét. A szerző ezt a szerteágazó feltételrendszer szerint előírt pályát nevezi technológiai fejlődéspályának, melyet a gazdaság egészére vonatkoztatva műszaki paradigmaként határoz meg. Ezekkel kapcsolatban megkülönbözteti a kialakulás, illetve szétterjedés időszakát. A paradigmaváltások és a technológiai forradalmak hatással vannak a világgazdaságra és befolyásolják annak fejlődését. Ezekből ötöt különböztetnek meg, amelyek nem mindig vannak átfedésben vagy összhangban egymással és a K-hullámok periódusaival, különös tekintettel a pontos kezdő és végpont meghatározásának vonatkozásában, ám a szerző tanulmányában kísérletet tesz összevetésükre. A technológiai forradalmak következtében új iparágak jönnek létre, az általuk létrehozott innováció átjárja a társadalmi-gazdasági rendszer egészét és új korszakba vezeti az emberiséget. Mind a müszaki-gazdasági paradigmák szakaszolása, mind a K-hullámok periódusainak pontos lehatárolása problémákat vet föl. Általában igyekeznek egy-egy szimbolikus eseményhez kötni az egyes szakaszokat (jelentős szabadalom vagy világméretű válság). Ám a válságok a műszaki paradigmák kialakulási, illetve szétterjedési időszakát választják ketté, így legalábbis hatással vannak azok alakulására, míg a K-hullámok esetében ez a hatás áttételesebb, így a szakaszolás utóbbiak esetében meglehetősen problematikus. Ennek ellenére elmondható, hogy a hosszú távú gazdasági növekedés gerjesztője a technológiai fejlődés és az innováció. Az előbbi megállapítások alapján elmondható, még ha nincs is teljes átfedés a két elmélet alapján felvázolt fejlödési pályák között, a párhuzamosítás lehetséges és léteznek átfedések, melyeket pontosan meg lehet határozni. A müszaki-gazdasági paradigmákat és a K-hullámokat elhelyező időtengelyek összevetése után megállapítható, hogy a két időtengely lefutása nagyon hasonló, de a ciklusok eltérő szinkronban mozognak. A müszaki-gazdasági paradigmák kialakulási időszakában érthetően lassúbb a gazdasági növekedés, mint a szétterjedés időszakában. Így a K-hullámok fellendülési szakaszai a müszaki paradigmák második szétterülő szakaszával vannak átfedésben. Ez kimutatható az 1929-es gazdasági válsággal kezdődő időszak esetében, ám az 1971-73-al kezdődő időszak esetében már nehezebb a pár- 
huzamosítás. A 2000-es éveket illetően elmondható, hogy az V. K-hullám kezdeti szakasza azonosítható az 1991-2007 közötti nagy megnyugvás időszakával, ám az 1990-es évek technológiai szempontból nem tekinthetők kiemelkedőnek, a 2000es évek válságai jelezhetnék a szétterülés fázisának kezdetét a műszaki-gazdasági paradigma esetében. Az anyaghoz két reflexió kapcsolódik az első Havas Attila: A műszaki és gazdasági fejlődés kapcsolata: elméleti és szakpolitikai megfontolások című tanulmánya. A szerző véleménye szerint jövőnket nem kizárólag az új technológiák határozzák meg. Szükséges a stratégiai gondolkodás is, erre támaszkodva lehetséges a jövő befolyásolása, így összehangolt döntésekkel hathatunk a változások irányára és sebességére. Ezzel kapcsolatban az egyes országok eltérő megközelítéseket alkalmaznak. Összességében azonban szükséges a szakpolitikai irányítási rendszer átalakítása, azaz a szakpolitikai célok módosítása, új döntési módszerek alkalmazása, új szereplők bevonása, új szereposztás kialakítása ahhoz, hogy az új technológiai forradalom hatásaira az államok, de az egyes gazdasági aktorok is megfelelöen reagálhassanak. Ebben fontos szerepe lehet a technológiai előretekintésnek, mely a hosszabb távú jövőre vonatkozó stratégiai elemzések egy fajtája. De ugyanolyan fontos a közös stratégiai gondolkodás folyamata, a résztvevők közötti párbeszéd a meglévő hálózatok erősítése, új hálózatok kiépítése is. Ezen együttmüködéseknek kormányzati ciklusokon átívelőknek kell lenniük, mivel e folyamatok és stratégiák kialakítása hosszabb időintervallumot fed le, ahogy a hatásaik is hosszabb távon határozzák meg a gazdaság és a társadalom fejlődését. A második a tanulmányhoz kapcsolódó munka Szalavetz Andrea: A technológia, a szakpolitika vagy a társadalom: Ki vezeti a táncot? az új müszaki gazdasági paradigma/a hatodik hosszú hullám idején? címet kapta. A szerző kiemeli, hogy egy új műszaki-gazdasági paradigma kialakítása sokszereplős játék. Az egyik fö kérdés az, hogy a szereplők közül ki vezeti majd a változásba az emberiséget, a technológia-szakpolitika-társadalom „szentháromságból”. A szereplők közül egyet sem lehet külön kiemelni, mely a hatodik paradigmát meghatározza, mivel bonyolult kölcsönhatásban vannak egymással. A radikális technológiai újítások hatásai következtében szükség van társadalmi innovációkra, illetve a szakpolitikai oldal hozzáállásának változására és a kapcsolódó szakpolitikák, valamint az elosztási rendszer reformjára. Ez kétség kívül bonyolult és az egész társadalmat-gazdaságot átható kérdés, ám fontos, hogy egyik szereplő se maradjon a parkett szélén, amikor a tánc majd véget ér.

A kötet második fejezete Szunomár Ágnes: Gazdasági csodák/gazdasági csapdák - Kínai növekedési kilátások a japán és dél-koreai példa tükrében címü munkája, mely Kína növekedésének kérdéseit vizsgálja. Az elemzés során a szerző Japán és Dél-Korea példájával párhuzamosítja a kínai gazdasági fejlődés gyorsulását, valamint irányváltásait, és ezek alapján ad előrejelzést a kínai gazdaság lehetséges jövőbeli fejlődési irányairól. A kínai növekedés az elmúlt időszakban lassulni látszik, így annak veszélye fenyeget, hogy Kína, hasonlóan több feltörekvő 
gazdasághoz, a közepes jövedelem csapdájába esik. Ennek elkerülése Kína alapvető érdeke, az ország célja, hogy hasonlóan több sikeres gazdasághoz (Szingapúr, Tajvan, Dél-Korea), átkerüljön a magas jövedelmű országok közé. Éppen ezért érdemes megvizsgálni Kína jelenlegi állapotát és lehetőségeit a közepes-jövedelem csapdájából való kitörésre. A szerző a jelenlegi kínai állapotot az 1977-es japán és az 1995-ös koreai állapottal veti össze, mivel ezek az időszakok az átalakulás évei az említett két országban. Természetesen a jelenlegi adatok összehasonlítására is sor került. A szerző a vizsgálatot, melynek során feltárta Kína felzárkózásának esélyeit és kilátásait a közepes jövedelmi csapda elkerülésére, három tényezőcsoport a strukturális átalakulás sajátosságai, a demográfiai jellemzők és az oktatás és innováció szerepe elemzésének segítségével folytatta le. Japán és Dél-Korea fejlődését és folyamatos gazdasági növekedését meghatározó termelékenyégnövekményt a technológiai fejlődés, az innovációk generálták. Kínában, ezzel szemben, a strukturális átalakulás váltott ki hasonló hatást. E strukturális átalakulás (termelési tényezők és beruházások újraelosztása) Kínában még folyamatban van és ez a közeljövőben is így lesz, míg Japán és Dél-Korea esetében már lezárult a magas jövedelemű országok csoportjába való átlépésük időszakára. Kína demográfiai szempontból a japán és a dél-koreai demográfiai fejlődést követi, hasonló problémákkal küzd (munkaerőhiány, elöregedő társadalom) még akkor is, ha gazdaságilag jelenleg nincs ez utóbbi két állam szintjén. Kína munkaerőmennyisége a jövőben folyamatosan csökkeni fog, ám emellett nő e munkaerő termelékenysége, mely hosszú távon táplálja a kínai növekedést. Ebből kifolyólag Kína jó eséllyel kerülheti el a közepes jövedelem csapdáját. Ezt támasztja alá, hogy az ország folyamatosan és sokat tesz azért, hogy növelje az oktatáshoz való hozzáférést és javítsa annak minőségét. Igaz, még nincs a másik két vizsgált ország szintjén, ám esélyei jók. Az előbbiek, valamint Japán és Dél-Korea példája alapján elmondható, hogy Kínának jó esélye van arra, hogy a további fejlödéshez szükséges humán tökét biztosítsa, sőt bővítse. Az innovációt illetően a helyzet az előbbinél jobb, lemaradása Japán és Dél-Korea mögött minimális. A teljes tényezőtermelékenységet tekintve, Japán és Dél-Korea adataival összehasonlítva, melyek a magas jövedelmi sávba való átlépéskor jellemezték az országokat, bíztató. Így összességében elmondható, hogy Kínának jó kilátásai vannak arra, hogy valóban elkerülje a közepes jövedelmi csapdát, és előreláthatólag 7-8 éven belül átkerüljön a magas jövedelmű országok csoportjába. Kérdés persze, hogy ezek után képes lesz-e elkerülni a „csapda utáni csapdát", melybe Japán és Dél-Korea került (stagnálás, negatív növekedés, defláció) már magas jövedelemü országként és melynek elemei, ha nem feltétlenül hangsúlyosan, de már most is jelen vannak az országban. Az értekezéshez Benczes István: és Muraközy László tanulmánya kapcsolódik. Benczes István: A közepes jövedelem csapdája: régi dilemmák újragondolva? címü írásában az elöző tanulmányban is vizsgált közepes jövedelem csapda koncepció újszerüségének kérdését vizsgálja. A közepes jövedelem csapdáját a 2000-es évek második felétől 
használják Kelet-Ázsia és Kína fejlődésével kapcsolatban. A múlt században számos ország sikeresen lépett át az alacsonyabb jövedelmű országok közül a közepes jövedelemủ országok csoportjába, ám ezután csak néhány országnak sikerült tovább lépnie a magas jövedelmű kategóriába. A munka azt vizsgálja, hogy újnak vagy újszerünek tekinthetö-e a közepes jövedelem csapdájának gondolata. A kérdést két irányból közelíti meg, egyrészt esettanulmány-szerüen elemzi Argentína, Malajzia és Vietnám fejlődését, másrészt a közgazdaságtan növekedési elméleteinek nézőpontjából is megvizsgálja azt. Végkövetkeztetése, hogy a közepes jövedelem probléma koncepciója - még ha oly népszerü is - napjainkban-nem újkeletü, sem a valóságban, sem az elmélet szintjén. Muraközy László: Japán, Korea és Kína: Útkövetés vagy útteremtés címü tanulmányában Japán és Dél-Korea fejlődésének tanulságaiból von le következtetéseket Kína gazdaságának lehetséges jövőbeli meghatározásához egy összehasonlító elemzés segítségével. Kína, bár profitálhat a japán és dél-koreai példából, ám különbözősége (népesség, kultúra, gazdaság, politikai berendezkedés) miatt, nem tekinthető az elöbbi kettőhöz hasonló fejlesztő államnak. Kínában az átalakulás felemás jelleget ölthet a szocialista politikai berendezkedés és kormányzás miatt. Illetve az állam jelentős gazdasági szerepvállalása és az erős központi kormányzati irányítás miatt más a bürokratikus és a piaci koordináció összekapcsolódása, mint a vizsgált másik két gazdaság esetében. Kína az innováció, a versenyképesség, a jól müködő, stabil piaci és pénzügyi intézményrendszer tekintetében jelenleg még nem éri el a fejlett országok szintjét. Különbség az említett két ország és Kína között hogy azok a világgazdaság egy korábbi, teljesen más korszakában kerültek a nekilendülés fázisába. A kínai modernizáció is a globalizáció kiterjedésének köszönhetően tudott megvalósulni, ám a magas szintű technológia és innováció nagyrészt kívülről érkezett. A kínai gazdaság eközben duális szerkezetü maradt. Az országban a növekedés fö forrásai az extrém mértékü megtakarítási és felhalmozási ráta és az olcsó, nagy mennyiségben rendelkezésre álló munkaerő voltak, e két tényező fenntartása hosszú távon nem lehetséges. A modernizációból és a fejlődésből adódó kihívások hosszú távon alááshatják a kormányzó elitek hatalmát, ahogy hasonló jelenség Japánban, Dél-Koreában vagy a világ bármely fejlett országában megtörténhet. Ez a központosítás erősödését hozhatja magával, amely irányba jelenleg az ország tart. Kína lehetőségei a jövőt tekintve jók, potenciálisan válhat globális gazdasági centrummá és akár a világpolitika vezető hatalmává is. Ám meg kell jegyezni, hogy a sajátos kínai fejlődésnek köszönhetően nem lesz képes követni a japán, és dél-koreai fejlődési mintát, és inkább az a valószínű, hogy nem lesz képes felzárkózni a világ és a térség sikeres gazdaságai közé.

A harmadik téma Oroszország fejlődésének kérdéseivel foglalkozik. Deák András tanulmányában Oroszország rendszerváltás utáni gazdasági fejlődését és átalakulását vizsgálja, ezáltal azt, hogy körülírható-e az orosz modell. Tanulmányában ezen orosz modellt mutatja be, vizsgálataiban kitér a modell sarokpontja- 
ira, illetve arra, hogy az menyiben tér el a többi kelet-közép-európai és kelet-európai volt szocialista állam átalakulásától. És végezetül, mennyire fenntartható a rendszer. Ennek kapcsán az orosz gazdasági rendszerről szóló tipológiai besorolásokkal kapcsolatos vitákat, a nyersanyagszektor és a demográfia viszonyát, majd a modernizáció és a szuverenitás kapcsolatát vizsgálja meg, végül kitekintést ad az orosz helyzettel kapcsolatban. Oroszország gazdaságtörténete az 1990-es évektől három eltérő évtizedre bontható. Az első a rendszerváltás időszaka, melyben végbement a rendszer átalakulása, de a gazdaság teljesítménye csökkent, a közállapotok konszolidáltalanok maradtak. Ezt az évtizedet egy bankválság, majd egy államcsőd zárta le. A második évtized, azaz Vlagyimir Putyin és etatista rendszere, tulajdonképpen a rendszerváltás és válság következményeire adott válasznak tekinthető. A „putyini” évtized átlagosan 7\%-os növekedést hozott a gazdasági helyzet, az életszínvonal érezhető javulásával. Ezt a belső körülmények és, természetesen, a külső körülmények pozitív alakulása is elösegítette. 2008 után egy sokkal negatívabb, ingadozó időszak következett, amikor az orosz gazdaság növekedése lassult. A rendszer előző harminc éve így a „turbulens átmenet-erőteljes konszolidáció-rezisztens stagnálás (pangás?)" hármassal írható le. Az orosz kapitalizmus nem a szovjet rendszer folytatása, a rendszer más, mint a többi volt szocialista ország esetében, maga mögött hagyta az alacsony jövedelmü országokkal kapcsolatos fejlődési problémákat, ugyanakkor nem tekinthető egyszerü nyersanyagexportőr államnak sem. A jólét mint legitimációs forrás, a nyugati demokráciák esetében fontos cél, ám Oroszország esetében elmondható, hogy a politikai rendszer fenntartásához nem feltétlenül szükséges a gazdasági növekedés, illetve a reformokhoz köthető jóléti legitimáció. A reform kifejezés a nyugati típusú gazdasági reformokhoz, az 1990-es évek reformjainak rossz emlékéhez köthető, és emiatt állami szinten kerülik a kifejezés használatát. A jelenlegi hozzáállás nyitva hagyja a társadalom jóléti igényeinek a kérdéskörét. A tulajdonviszonyok és a vagyoni egyenlőtlenségek szempontjából megkerülhetetlen, hogy a növekedéssel kapcsolatos veszteségek egyik oka a politikailag befolyásolt tulajdonosi viszonyok és az, hogy a gazdaság nem a kibocsátás, hanem a hatalmon lévő csoportok kifizetéseinek maximalizálását tüzte ki célul. Ez az oligarchikus berendezkedés az orosz rendszer egyik legyakrabban említett vonása, ám nem gyakorolt jelentős hatást az elmúlt időszak fejlődésére. Kelet-Közép Európához képest a külföldi befektetések csak később, a 2000-es évek közepétől váltak jelentőssé és ma már számottevően jelen vannak Oroszországban. Ugyanakkor csökkentek a vagyoni egyenlötlenségek, még akkor is, ha azok a brazil, dél-afrikai szinten vannak. Oroszországban nem alakult ki a Latin-Amerikára jellemzö „elitista diktatúra - populista demokrácia” váltógazdaság, de a posztszovjet térség kleptokratikus rendszereihez hasonló állapot sem, annak ellenére, hogy a posztszovjet nómenklatúra szilárdan tartja a helyét és létrejött a már említett oligarchikus berendezkedés. Oroszország rendszerét e vonásai alapján többen a gyenge-erős állam, káosz-diktatúra kettősség, 
vagy a nemdemokratikus államok politikai gazdaságtana alapján határozzák meg. Oroszország a világ egyik legjelentősebb olaj- és gáztermelöje, de a magas népességszám és a magasabb fejlettség miatt a nyersanyagexportból származó bevételek csak gyenge közepes függést okoznak. Ugyanakkor jelen van a korrupció, mellyel kapcsolatban nehéz megítélni, hogy az mennyire jelent rendszeralkotó tényezőt az orosz kapitalizmus működését illetően. Összességében mennyiben különleges az orosz eset? Az orosz átmenet modelltelen volt, nem volt elöre eltervezett forgatókönyve. A gazdasági rendszerváltásban nem volt konszenzus, nem volt nemzeti kerekasztal. Nem volt egyértelmű a domináns tulajdonforma kérdése, az állami szerepvállalás mértéke és mikéntje, a piaci intézmények formái. Oroszország útja a kínai modelltől is különbözö, hiszen Oroszország nem alulfejlett volt, mint Kína, hanem félrefejlődött, ahol a politikai stabilitás és a külgazdasági nyitás még nem hozott volna egyértelműen felzárkózást. Az orosz átmenet tulajdonképpen ugrás volt a sötétbe, melyet sokkal inkább meghatározott a tehetetlenség, mint a pontos és elöre kitűzött célrendszer. Oroszország jelenleg is meghatározó világpolitikai szereplö, és célja annak is maradni. Ez még inkább árnyalja viselkedését, és befolyásolja rendszerének alakulását. Az olajszektor és az abból származó export felhasználásának intézményesülése és menedzselése, illetve az abból származó jövedelmek kezelése egyre javul az országban. A terület igen fontos az ország gazdasági teljesítménye szempontjából, és alapvetően kiegyensúlyozottabb teljesítményt nyújtott az elmúlt időszakban, mint a szovjet időkben. E szektornak köszönhetően a rendszerváltás következtében létrejött átalakulás következményei enyhébbek voltak, mint a posztszovjet térség egyéb államai esetében. Az alapvető iparpolitika tekintetében azonban a mai napig nincs konszenzus a társadalom és a gazdasági vezetés szintjén. Nem eldöntött, hogy a fokozatos fejlesztéspolitika vagy a csúcstechnológiákba való ugrásszerű átlépés segítségével szeretnék elérni a modernizációt. Ha volna egy világos irány, az a kitermelő szektorra és ezen belül a szénhidrogéntermelésre is pozitívan hatna egy esetleges reform tekintetében. Az orosz gazdaság diverzifikálásának kérdése megmutatta azt, hogy az ország gazdaságának átalakítása modernizációja tekintetében a kitermelő ágazatnak és a nyersanyagexport kiegyensúlyozó hatásának milyen határai vannak. Emellett meg kell említeni, hogy az orosz gazdaságpolitikának lehet mozgástere a 2020-as években jelentkező, a technológiaváltás következtében létrejövő problémák kezelésében az olaj és földgázszektor területén. A népességszám és a korösszetétel vonatkozásában fogyatkozó, illetve elöregedő tendenciát mutat az ország. Ez növelheti a regionális egyenlötlenségeket, illetve erősítheti a társadalmi feszültségeket. Hosszú távon a jelenleg nem túl jó állapotú szociális és nyugdíjrendszer átalakulásához vezethet. Ezek alapján az Oroszország egy leszakadó gazdaság képét nyújtja. A viszonylag elszigetelt orosz állami vezetés szempontjából kiemelt fontosságú a nagyhatalmi szerep megőrzése, melyet csak kiszolgál a gazdasági fejlődés. Ebből következően a rendszerre leselkedő veszélynek tekintenek egy lehetséges külpoli- 
tikai megaláztatást, a szuverenitás részleges elvesztését vagy a belső viszonyok megbomlását, de a gazdasági lemaradást vagy a jóléti növelésére tett kisérletek sikertelenségét nem így ítélik meg. Ezt bizonyítja az orosz külpolitika iránya, illetve Oroszország viselkedése a nemzetközi konfliktusokat illetően. Az orosz gazdaság más megfontolások alapján müködik és reagál a válságokra, mint a többi európai gazdaság. A nyugati modell részleges elvetése, a nyersanyagexport jelentősége a gazdaságban, a Kelet-Ázsia irányába történő nyitás és a kapcsolatok erősítése, a protekcionista gazdaságpolitika alkalmazásának lehetősége, a társadalmilag beágyazott államszerep és az orosz külpolitikai iránya és saját meghatározása, mind megkülönböztetik a többi rendszerváltó posztszocialista országtól. A távolodás ezektől a modellektől, az ország adottságainak figyelembe vételével, nem feltétlenül kedvezőtlen, ám kevés érv hozható föl amellett, hogy ennek alapján Oroszország fel tud majd zárkózni a fejlett országok csoportjához. A tanulmányhoz két szerző Kalotay Kálmán és Sz. Bíró Zoltán füzött megjegyzéseket: Kalotay Kálmán: Észrevételek az „orosz modellröl” - egy értékes vitaanyag kapcsán, megjegyzi hogy ha létezik orosz modell, az jelentős részben mennyiségi alapú. Az orosz gazdaság képes a válságokat kezelni, ám lemaradása a versenytársakhoz képest jelentős és ezt nehéz összeegyeztetni az orosz nagyhatalmi tudattal és elképzelésekkel. Az orosz modell és az orosz fejlődés sikerességét és irányát nehéz meghatározni. A gazdaság elmúlt harminc évét nem lehet sikertelennek tekinteni, ám elmondható hogy összességében az orosz gazdaság a többi nagyhatalomhoz képest jelentősen leszakadt. A további leszakadás megakadályozása, illetve a hátrány ledolgozásához szükség van az ország gazdasági szerkezetének diverzifikálására. Ezt elősegítheti a 2014 után kialakult helyzet, mely az orosz gazdaságot importhelyettesítő irányba fordította. Ez a pálya hatékonyabb lehet a gazdaság diverzifikálása, esetleges új alapokra helyezése szempontjából, mint a nyersanyagexportra alapozott gazdasági növekedés politikája. Még akkor is, ha nem exportorientált, hanem protekcionizmusra építő diverzifikációs stratégia alapján jön létre. Az orosz jövő attól is függ, hogyan tud majd az ország alkalmazkodni az „új ipari forradalom”-hoz. Sz. Bíró Zoltán: Megjegyzések Deák András Van-e orosz modell? címü, az előadáshoz kapcsolódó megjegyzéseiben felhívja a figyelmet arra, hogy a szovjet korszakban kiadott statisztikai adatok megbízhatósága nem a legmegfelelőbb. Így igen nehéz Oroszország egyes történelmi korszakokban nyújtott gazdasági teljesítményét összevetni, Így van ez az ország jelenlegi gazdasági teljesítménye esetében is. 2001 elején, a putyini rendszer elindulásakor, Oroszország kapcsolatai a nyugati hatalmakkal megfelelőek, sőt jók voltak. Ez a kapcsolatrendszer a 2000-es évek közepétől erodálódott, majd az évtized végétől fokozatosan az elszigetelődés jegyeit kezdte mutatni. Ezt 2010-ben még sikerült visszafolytani ám végül e folyamat betetőzése volt a Krím-félsziget annektálása, majd az ukrajnai polgárháború eszkalálódása. Emellett a 2008-as válság is érzékenyen érintette az orosz gazdaságot, melyre a külpolitikai lépések következtében bevezetett nyugati 
szankciók csak ráerősítettek. Ám a rendszer belső népszerűsége töretlen maradt, hiszen az orosz gazdaság, nem kis részt a nyersanyagexportnak köszönhetően, 2000 és 2007 között mintegy 7\%-os évi gazdasági növekedést produkált, mely az életszínvonal növekedését is magával hozta. A gazdasági problémák következtében, nem kis mértékben a politikai rezsim fenntartása érdekében, a rendszer addigi jóléti alapú legitimációját fokozatosan identitásalapúra cserélték, melyhez a külpolitikai események (különösen az Ukrajna orosz kisebbséggel szembeni viselkedése) jó alapot nyújtottak. A kormányzat jelenleg is szigorú ellenőrzés alatt tartja a gazdaság stratégiai ágazatait, ez a közeljövőben sem fog változni. A rendszer legitimációja erős, ám kérdés az, hogy a nagyhatalmi nosztalgia és ambíció léggömbje meddig emelkedik, meddig tudja elfeledtetni a lakossággal a romló életkörülményeket, a növekvő vagyoni különbségeket, a lemaradást, mielőtt végleg leeresztene vagy szétdurranna.

A negyedik fejezetben a világkereskedelem jelenlegi helyzetét és lehetséges átalakulását vizsgálják meg a szerzők. A témát Kiss Judit Átalakulóban a világkereskedelem? címü értekezése vezeti be, melyben a szerző ismerteti a világkereskedelem jelenlegi folyamatait. A szabadkereskedelem versus protekcionizmus dilemmát, illetve a legjelentősebb gazdasági szereplők hangsúlyváltásait a témát illetően, azaz a versenyképességi viszonyokban és a gazdasági súlyban, a világkereskedelemre gyakorolt befolyásban bekövetkezett változásokat. A világkereskedelem a 2000-es évek eleje óta fontos változásokon ment keresztül. A 2008-as válság rámutatott a világkereskedelem sérülékenységére, az a válságból sikeresen kilábalt és elkezdődött a strukturális átalakulása, de növekedési dinamikáját nem nyerte vissza. A világkereskedelem legjelentősebb szereplői, az Európai Unió, az USA, Kína és Németország. A világkereskedelem növekedését egyre kisebb mértékben határozzák meg a fejlett országok, ez 2008 után még hangsúlyosabb lett. A világkereskedelem egyre inkább hálózatosodik a munkamegosztás elmélyülése, az országok nyitottságának növekedése, a globalizálódó értékláncok kialakulása következtében. Emellett új erőközpontok - például Kína - jelennek meg. A világ legjelentősebb kereskedelmi blokkja az Európai Unió, a három legjelentősebb exportőr Kína, az USA és Németország, a legjelentősebb importőrök az USA, Kína és Németország. Így az USA és Kína a két legjelentősebb kereskedő a világkereskedelemeben, melynek összetétele a magas feldolgozottságú és a magas technológiaigényű termékek irányába változott. Ebben jelentős szerepük van a multinacionális nagyvállalatoknak és értékláncoknak. A fejlett országok az egyre jelentősebb szolgáltatáskereskedelem területén dominánsok, míg a feltörekvő ázsiai országok - ezeken belül Kína - a hagyományos árukereskedelemeben jelentősek. Az árucsere-forgalom nagy koncentrációt mutat: az Európai Unió az 1/3-át, az első 10 ország az 52\%-át adja, így az abból származó előnyök, ahogy maga a világkereskedelem is jelentős egyensúlytalanságokat mutat. A kiegyensúlyozásra való törekvések, az erőviszonyok esetleges megváltozása kereskedelmi háborúkat 
robbanthat ki, ezek a konfliktusok jelen helyzetben mind az azt kirobbantó, mind azt elszenvedő, de a konfliktusban közvetlenül részt nem vállaló szereplők számára is igen nagy károkat okozhat. Ráadásul az ilyen konfliktusok kimenetele is kétséges, pláne ha regionális vagy globális méretűvé eszkalálódnak. Minél nagyobb a kereskedelmi háborúban résztvevő országok száma, a konfliktus annál kiszámíthatatlanabbá válik, különösen, ha az globális méretűvé válik. A Kína és az Amerikai Egyesült Államok közötti konfliktus megmutatta az ilyen típusú ellentétek lehetséges hatásait. Azáltal, hogy a két ország konfliktusa az egész világkereskedelemben éreztette befolyását. Ily módon a konfliktus kihathat a többi országra is, mivel erodálhatja a világkereskedelem intézményesített, multilaterális szabályozását, és erősítheti a protekcionizmust a szabadkereskedelemmel szemben. A Kína és az USA között kialakult kereskedelmi háború eszkalálódása esetén okozott legnagyobb kár nem a vámok emelésének következtében lecsökkenő kereskedelmi forgalomból származna, hanem a globális értékláncokra mért romboló hatásból. Korunk világgazdasága egy globálisan összetett, bonyolult, sokdimenziós rendszernek tekinthető. A kölcsönös függésen keresztül ezer szálon összefonódott ez a rendszer, még akkor is, ha az összefonódások sokszor aszimmetrikusak. A világgazdaság aktorai ennek köszönhetően motiváltak a globalizációs folyamatokból következő előnyök jobb fölosztásában. Ezért igyekeznek a folyamatos liberalizációt támogatni és a kereskedelem útjában álló akadályok lebontását elősegíteni. Ennek folyamata már a második világháború utáni időszakban elindult, globálissá azonban csak a bipoláris világrend fölbomlása után vált. Fentiek elősegítése mind bi- vagy multilaterális együttmüködéseken keresztül, regionális gazdasági integrációkon át egészen a WTO keretében kialakított együttműködések felhasználásával valósulhat meg. A világkereskedelem globalizációja, a kialakult értékláncok és a gazdaságok összekapcsolódása azonban indokolttá teszi a világkereskedelem kiszámítható multilaterális szabályozását. Hazánknak európai uniós tagállamként fontos egy olyan liberalizálódó világkereskedelem kialakítása és működése, mely mentes a kereskedelmi konfliktusoktól és gazdasági háborúktól és amelyben a megmarad a piacok diverzifikálásának lehetősége.

A téma kiegészítéséhez illetve az anyaggal kapcsolatos megjegyzéseik alapján két szerző készített tanulmányt, Balás Péter: Megjegyzések a világkereskedelem aktuális helyzetéről, átalakulásáról rendezett konferenciához és Erdey László: Átalakulóban a világkereskedelem? - Kereskedelemelméleti és kereskedelempolitikai megfontolások címmel. Az első kiegészítésben Balás Péter elsősorban az EU-t érintő változásokra koncentrál. Felhívja a figyelmet a nemzetközi kereskedelmi adatok elemzése során előálló gyakori, az adatminőségből adódó problémára. Megjegyzi, hogy az Európai Uniót a 28 -ak tekintetében egységesen lehetett volna kezelni. Illetve, a szerző hozzáállása, véleménye szerint a világkereskedelmi tendenciákkal kapcsolatban túlságosan optimista. Az USA rendhagyóan úgy viselkedik, miszerint partnerei az állami beavatkozások gazdaságélénkítő hatása- 
in keresztül (melyek saját szereplöiket segítik) beavatkoznak a piaci viszonyokba, ezáltal torzítják a versenyt és ez nyilvánvaló csalás, mely minden az USA-val kapcsolatban álló államra jellemző. Éppen ezért elvárása, hogy e partnerek egyoldalúan nyissanak piacot az amerikai szereplők elött, inkább politikai, mint valóság alapú indíttatás, mivel ebben a tekintetben nem lehet egy kalap alá venni az Európai Uniót, Japánt vagy Oroszországot és Kínát. Véleménye szerint célszerü lenne az USA-Kína kereskedelmi konfliktust kiegészíteni szélesebb nemzetközi összefüggésekkel gazdasági-jogi vonatkozásokkal. Erdey László véleményében kifejti, kiegészítve a szerző írását, hogy a nemzetközi áru- és szolgáltatásforgalom átalakulása nincs ellentmondásban az elmúlt 30-40 év kereskedelemelméleti újításaival, sőt kifejezetten összecseng azon megállapításokkal, amelyek a globalizáció szakaszainak, a multilaterizmusnak és a kereskedelempolitikának az újragondolását szorgalmazzák. Napjaink nemzetközi politikájára és világkereskedelmére egyértelműen hatással volt két esemény: az egyik a 2016-os Brexit népszavazás eredménye, a másik pedig 2016-ban Donald Trump elnökké választása. Az új elnök leállította az USA részéről a Transz-csendes-óceáni Partnerséggel kapcsolatos tárgyalásokat, kereskedelmi háborúval fenyegető ígéreteket tett több kereskedelmi partnere felé (ezeket Kínával kapcsolatban tettekre is váltotta), kritizálta és hátráltatta a WTO vitarendezési mechanizmusát és hozzákezdett egyik választási ígérete betartásához, miszerint újratárgyalja a NAFTA egyezményt Kanadával és Mexikóval. Ezen lépései összességében negatívan befolyásolhatják nemcsak az USA világkereskedelmi szerepét, de a nemzetközi kereskedelem megfelelő működését is. A világ fejlett országai a XXI. században új helyzetben találták magukat. Fennáll annak a veszélye, hogy az általuk megteremtett globalizáció új vívmányainak következtében a globalizáció következő új szakasza már nem nyertesekként, hanem vesztesekként éri majd őket. Nem törvényszerü hogy a jövőben a világgazdaság átalakulása után ezen országok továbbra is centrumtérségek maradnak. Ugyanakkor e változások erőteljesebben az alacsonyabb képzetséggel rendelkezőket sújtják, így erősítve a társadalmi feszültségeket, utat engedve a populista politikáknak és az anti- vagy deglobalista hozzáállásnak. Mára egyre inkább elfogadottá válik a rodriki trilemma, miszerint egyszerre nem kivitelezhető a hiperglobalizáció, a demokrácia és a nemzeti szuverenitás. A háromból csak kettővel rendelkezhetünk egy időben.

A kötetben ismertetett négy témakör időszerü és napjainkban fontos kérdéseket vizsgál melyek korunk világgazdaságának meghatározó területei. A munka hasznos áttekintést nyújt azok számára, akik a világgazdaság aktuális kérdései iránt érdeklődnek, de azoknak a szakembereknek is érdekes ismereteket nyújthat, akik gazdasági területeken kutatnak., nem csak az eredményeik, de vitaindító felvetéseik segítségével is. 


\section{Hivatkozások}

Szanyi Miklós-Török Ádám (szerk.) (2019): Trendek és töréspontok. Akadémiai Kiadó, Budapest

A kötet tanulmányai:

Balás Péter (2019): Megjegyzések a világkereskedelem aktuális helyzetéről, átalakulásáról rendezett konferenciához. 253-259. o.

Benczes István (2019): A közepes jövedelem csapdája: régi dilemmák újragondolva? 108-121. o.

Deák András (2019): Létezik-e orosz modell? Gazdasági útkeresés és modernizáció Oroszországban. 149-188 o.

Erdey László (2019): Átalakulóban a világkereskedelem? - Kereskedelemelméleti és kereskedelempolitikai megfontolások. 260-277. o.

Havas Attila (2019): A műszaki és gazdasági fejlődés kapcsolata: elméleti és szakpolitikai megfontolások. 39-61. o.

Kalotay Kálmán (2019): Észrevételek az „orosz modellről” - egy értékes vitaanyag kapcsán. 189-205. o.

Kiss Judit (2019): Átalakulóban a világkereskedelem? 215-252. o.

Muraközy László (2019): Japán, Korea és Kína: Útkövetés vagy útteremtés. 122146. o.

Sz. Bíró Zoltán (2019): Megjegyzések Deák András Van-e orosz modell? című írásához. 206-212. o.

Szalavetz Andrea (2019): A technológia. a szakpolitika vagy a társadalom: „Ki vezeti a táncot" az új müszaki gazdasági paradigma/a hatodik hosszú hullám elején? 62-69. o.

Szanyi Miklós (2019): Müszaki fejlődés és hosszú távú gazdasági ciklusok. 13-38. o. Szunomár Ágnes (2019): Gazdasági csodák/gazdasági csapdák-Kínai növekedési kilátások a japán és dél-koreai példa tükrében. 73-107. o.

Török Ádám-Szanyi Miklós (2019): Előszó - A Világgazdasági Tudományos Tanács 2017-2018-as működése és a megvitatott témák. 7-10. o. 